[Bull. Agr. Chem. Soc. Japan, Vol. 24, No. 3, p. 324 325, 1960]

\title{
Isolation of (+)-Neoiso-isopulegol, a New Stereoisomer of Isopulegol and Piperitenone from a Variety of Mentha rotundifolia
}

\author{
Studies on the Essential Oil of Mentha rotundifolia. Part V*
}

Sir :

In the previous report, ${ }^{11}$ one of the authors has established that the rotundifolia oils of European origin contain rotundifolone (piperitenone-1,2-epoxide) (I) as the principal component. However, the oil obtained from the French strain $^{* *}$ was levo-rotatory and had an absorption at $235 \mathrm{~m} \mu$, while the normal oil containing rotundifolone showed highly dextrorotatory value and intense absorption at $260 \mathrm{~m} \mu$.

The carbonyl fraction separated from the French strain oil by bisulfite method, had two maxima, 238 and $275 \mathrm{~m} \mu$. It yielded at first orange red 2,4-dinitrophenylhydrazone, m.p. $157^{\circ} \mathrm{C}$, which gave deep red crystals of m.p. $184^{\circ} \mathrm{C}$ from a hardly soluble part in methanol. Its analysis coincided well with the value calculated for piperitenone 2,4-dinitrophenylhydra- which was obtained from (I) by lithium aluminum hydride ${ }^{1)}$, b.p. $105 \sim 107^{\circ} \mathrm{C} / 10 \mathrm{~mm}, \lambda_{\max }^{\mathrm{MeOH}}$ $242 \mathrm{~m} \mu(\log \varepsilon 4.0)$, and $275 \mathrm{~m} \mu(\log \varepsilon 3.8)$. It gave 2,4-dinitrophenylhydrazone of m.p. $184^{\circ} \mathrm{C}$ and agreed with the value by Naves ${ }^{22}$. It also did not show any depression on admixture with our French strain rotundifolia hydrazone, mentioned above.

Besides the isolation of piperitenone, piperitone 2,4-dinitrophenylhydrazone was obtained as orange red needles of m.p. $116^{\circ} \mathrm{C}$ from the methanol soluble part. The presence of piperitone was also proved by the fact that its semicarbazone, m.p. $218^{\circ} \mathrm{C}$ was undepressed when mixed with authentic piperitone semicarbazone from a Japanese peppermint oil ${ }^{3)}$, while piperitenone did not give any crystalline substance by the same treatment ${ }^{4}$.
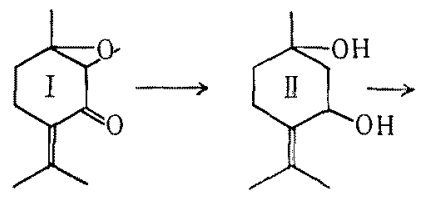<smiles>CC1=CC(=O)C(=C(C)C)CC1</smiles><smiles>CCCCCCCCCCCCCCCCCC</smiles><smiles>CCCC1CCCCC1O</smiles>

$\mathrm{LiAlH}_{4}$ Oppenauer
Oxidation

$(-)$-isopulegol

(4) -neoiso-isopulegol zone; Anal. Found for $\mathrm{C}_{16} \mathrm{H}_{18} \mathrm{O}_{4} \mathrm{~N}_{4}, \mathrm{C}, 58.67$ $\mathrm{H}$, 5.74, N, 17.02. Piperitenone (III) was prepared by the Oppenauer oxidation of (-)hydroxypulegol (II) of m.p. $145^{\circ} \mathrm{C},[\alpha]_{10}^{10}-58^{\circ}$,

* This report was presented at the 3rd Mecting of Chem. Perfume, Terpene and Essential Oil at the Univ. of Tokyo on Oct. 20. 1959.; Part IV of this series; S. Shimizu and $N$ Ikeda, This Bulletin, 22, 201 (1958).

** The seeds of this Mentha rotundifolia were imported from Jardin Botanique de Tollouse, France in 1955 and cultivated at Okayama Univ., Japan. This variety was named the French strain in this series, since it showed different aspects as reported previously.
The oil, from which unsaturated ketones were removed by bisulfite method, was fractionated and the fraction, b.p. $68^{\circ} \mathrm{C} / 3 \mathrm{~mm}$ was treated with excess of 3,5-dinitrobenzoylchloride to give colorless needles of m.p. $91^{\circ} \mathrm{C}$ in $40 \%$ yield. Its analysis coincided with the value for isopulegol 3,5-dinitrobenzoate; Anal. Found for

1) S. Shimizu, This Bulletin, 21, 113 (1957)

2) Y.R. Naves, Bull. soc. cbim. France, 1951, 370.

3) S. Shimizu, Journal of Sbinsbu Unin., No. 4, 299 (1954).

4) W. Kuhn and H. Schniz, Helv. 36, 167 (1953). 
$\mathrm{C}_{17} \mathrm{H}_{20} \mathrm{O}_{6} \mathrm{~N}_{2}, \mathrm{C}, 59.03, \mathrm{H}, 5.76$. The free alcohol was obtained by digesting benzoate with an alcoholic potash; b.p. $96^{\circ} \mathrm{C} / 15 \mathrm{~mm}, n_{\mathrm{D}}^{10} 1.4775$, $[\alpha]_{\mathrm{D}}^{10}+4.04$. Its infrared spectrum showed the characteristic absorption bands for isopropenylgroup, 1640 and $895 \mathrm{~cm}^{-1}$.

Theoretically, isopulegol can exist in four configurations and the three isomers except for neoiso-form had been reported by Pickard ${ }^{53}$, Read $^{6)}$, Komatsu ${ }^{7}$ and Ueda ${ }^{8)}$. However, our substance did not have agreeable constants with anyone of isopulegol isomers, above mentioned. Our isopulegol absorbed $1 \mathrm{~mol}$ of hydrogen over $\mathrm{Pto}_{2}$ in glacial acetic acid to yield viscous oil of menthol-like ordor; $100 \sim 105^{\circ} \mathrm{C} / 20 \mathrm{~mm}, n_{\mathrm{D}}^{10}$ $1.4660,[\alpha]_{D}^{10}+0.10^{\circ}$. Its infrared spectrum was completely identical with that of (+)-neoisomenthol reported by one of the authors ${ }^{9)}$ and Naves ${ }^{10}$. Our hydrogenated alcohol also gave 3,5-dinitrobenzoate, m.p. $101^{\circ} \mathrm{C}$, which was not depressed by mixture with (+)-neoiso-menthyl3,5-dinitrobenoate, m.p. $99.5 \sim 100.5^{\circ} \mathrm{C} . .^{\circ}$ ) Since the hydrogenation of isopropenyl group does not concern with asymmetric carbon, the original new alcohol in the rotundifolia oil from the French strain can be assigned to be $(+)$-neoisoisopulegol. It is well known that natural isopulegol reported by Naves ${ }^{11}$ and Penfold ${ }^{12}$

5) R. H. Pickard, H. Hunter, W. Lewcock and H de Penrigton, J. Chem. Soc., 117, 1248 (1920).

6) J. Read, J. Chom. Soc., 1930, 1939

7) A. Konnatsu, J. Chem. Soc. Japan (in press).

8) H. Ueda and S. Shimizu, This Bulletin (in preess).

9) H. Ueda and T. Mirsui, J. Agr. Chem. Soc. Japat, 28, 945 (1954).

10) Y.R. Naves and J. Lecomte, Bull. soc. chim., 1955, 792.

11) Y. R. Naves, Parfumes France, 6, 191 (1928):9, 69 (1931).

12) A. R. Penfold, J. Pros. Roy. Soi., 65, 185 (1932). and synthetic isopulegols ${ }^{5,6,13>}$ obtained by cyclization of citronellal in acid media have isopropenyl group at $\mathrm{C}_{4}$ in trans position to $\mathrm{C}_{1}$ methyl and is related to (-)-menthol. Naves ${ }^{113}$ also pointed out that isopulegol occurs only in those oils of which citronellal is also a constituent. On the other hand, isopropenyl group of rotundifolia neoiso-isopulegol being cis at $\mathrm{C}_{4}$ and the presence of citronellal was not detected. This fact should not be neglected for investigation of cyclic terpene biosynthesis from acyclic compounds. Furthermore, the French strain rotundifolia contains piperitenone but not rotundifolone (piperitenone oxide), which is usually found in many strains of Mentha rotundifolia. So it seems to us that the French strain may lack the enzyme catalizing piperitenone to its oxide, which has some connection with neoisoisopulegol formation. These specific aspects of the French strain are also noteworthy to interpret the essential oil formation in the various Mentha plants from a view of biochemical genetics.

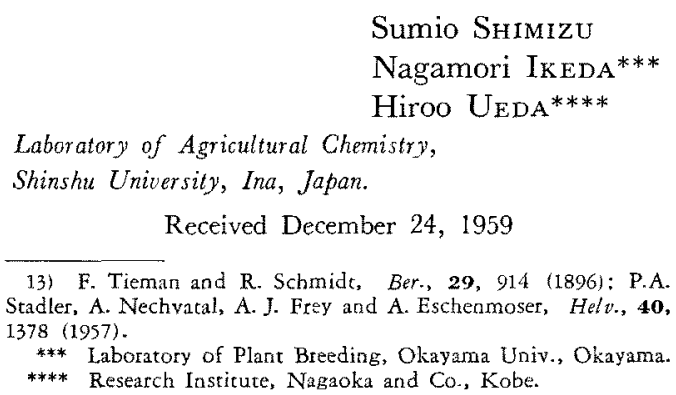

Nagamori IKEDA***

iroo $\mathrm{UEDA}^{* * * * *}$

Laboratory of Agricultural Chemistry, Received December 24, 1959

\footnotetext{
Stadler, A. Nechvatal, A. J. Frsy and A. Eschenmoser, Helv., 40,

***** Research Institute, Nagaoka and Co, Kobe.
} 